\title{
Life-cycle assessment of greenhouse gas emissions from dairy production in Eastern Canada: A case study
}

\author{
E. J. Mc Geough, S. M. Little, H. H. Janzen, T. A. McAllister, S. M. McGinn, and K. A. Beauchemin ${ }^{1}$ \\ Agriculture and Agri-Food Canada, Lethbridge, AB, Canada, T1J 4B1
}

\begin{abstract}
The objective of this study was to conduct a life-cycle assessment (LCA) of greenhouse gas (GHG) emissions from a typical nongrazing dairy production system in Eastern Canada. Additionally, as dairying generates both milk and meat, this study assessed several methods of allocating emissions between these coproducts. An LCA was carried out for a simulated farm based on a typical nongrazing dairy production system in Quebec. The LCA was conducted over $6 \mathrm{yr}$, the typical lifespan of dairy cows in this province. The assessment considered 65 female Holstein calves, of which 60 heifers survived to first calving at 27 mo of age. These animals were subsequently retained for an average of 2.75 lactations. Progeny were also included in the analysis, with bulls and heifers in excess of replacement requirements finished as grain-fed veal $(270 \mathrm{~kg})$ at $6.5 \mathrm{mo}$ of age. All cattle were housed indoors and fed forages and grains produced on the same farm. Prefarm gate GHG emissions and removals were quantified using Holos, a whole-farm software model developed by Agriculture and Agri-Food Canada and based on the Intergovernmental Panel for Climate Change Tier 2 and 3 methodologies with modifications for Canadian conditions. The LCA yielded a GHG intensity of $0.92 \mathrm{~kg}$ of $\mathrm{CO}_{2} \mathrm{Eq} / \mathrm{kg}$ of fat- and protein-corrected milk yield. Methane $\left(\mathrm{CH}_{4}\right)$ accounted for $56 \%$ of total emissions, with $86 \%$ originating from enteric fermentation. Nitrous oxide accounted for $40 \%$ of total GHG emissions. Lactating cows contributed $64 \%$ of total GHG emissions, whereas calves under 12 mo contributed $10 \%$ and veal calves only $3 \%$. Allocation of GHG emissions between meat and milk were assessed as (1) $100 \%$ allocation to milk, (2) economics, (3) dairy versus veal animals, and (4) International Dairy Federation equation using feed energy demand for meat and milk production. Comparing emissions from dairy versus veal calves resulted in $97 \%$ of the emissions allocated to
\end{abstract}

Received December 5, 2011.

Accepted April 13, 2012.

${ }^{1}$ Corresponding author: karen.beauchemin@agr.gc.ca milk. The lowest allocation of emissions to milk (78\%) was associated with the International Dairy Federation equation. This LCA showed that greatest reductions in GHG emissions would be achieved by applying mitigation strategies to reduce enteric $\mathrm{CH}_{4}$ from the lactating cow, with minimal reductions being achievable in young stock. Choice of coproduct allocation method can also significantly affect the relative allocation of GHG emissions to milk and meat.

Key words: coproduct allocation, Eastern Canada, greenhouse gas emissions, life-cycle assessment

\section{INTRODUCTION}

Animal agriculture generates significant amounts of potent greenhouse gases (GHG), about 8 to $10 \%$ of global anthropogenic emissions, and even more (18\%) if emissions from land-use change are included (O'Mara, 2011). Given the effects of increasing GHG levels on climate change and the growing demand for food to meet population increases, mitigation of these emissions has been a focal point in agricultural research.

Of particular interest to the dairy industry is methane $\left(\mathrm{CH}_{4}\right)$, generated primarily from microbial fermentation of feed in the gastrointestinal tract of ruminants. Besides its potency as a $\mathrm{GHG}, \mathrm{CH}_{4}$ also represents energy loss for the animal, accounting for 0.02 to 0.12 of gross energy (GE) intake (Johnson and Johnson, 1995). Numerous reviews have assessed potential $\mathrm{CH}_{4}$ mitigation strategies (e.g., Boadi et al., 2004; Beauchemin et al., 2008); however, to successfully reduce the environmental impact of dairying, reductions in $\mathrm{CH}_{4}$ must not come at the expense of higher carbon dioxide $\left(\mathrm{CO}_{2}\right)$ and nitrous oxide $\left(\mathrm{N}_{2} \mathrm{O}\right)$ emissions. Thus, to accurately assess the net impact of dairying on GHG emissions, it is necessary to quantify all emissions and removals using whole-system analysis or life-cycle assessment (LCA).

Life-cycle assessment is a holistic tool used not only in agriculture but also across industries for quantifying the carbon footprint of a variety of specific products. According to the International Organization for Standardization (ISO, 2006), LCA is defined as the compilation and evaluation of the inputs, outputs, and 
potential environmental impact of a product system throughout its life cycle. This methodology reports the GHG intensity of a system, expressing emissions relative to a functional unit. In dairy systems, the functional unit is commonly $1 \mathrm{~kg}$ of fat- and proteincorrected milk (FPCM). However, dairy production may be defined as multifunctional, whereby meat is also generated as a saleable product. Several methodologies, based on ISO (2006) guidelines, can allocate emissions across these coproducts, but choice of methodology affects estimates of GHG intensity of dairy products (Cederberg and Stadig, 2003; Flysjö et al., 2011a).

In Canada, most dairying occurs in Eastern Canada; Quebec alone accounts for $37.5 \%$ of the national dairy cow herd (Canadian Dairy Information Centre, 2011b). Dairying here is typically nongrazing [C. Bérubé (AgriAction Montérégie, Quebec, Canada) and T. deVries (University of Guelph Ontario, Canada), personal communication], with $92 \%$ of dairy cows housed in tie-stalls (Canadian Dairy Information Centre, 2011a), relying on feed crops grown on cultivated farmland. To date, only 1 study (Vergé et al., 2007) has examined the GHG emissions for the Canadian dairy industry, and that study was an industry-wide top-down analysis, rather than a farm-based study.

The objectives of this study were first to use a partial LCA to determine and allocate among sources the whole-farm GHG emissions of a typical nongrazing dairy system up to the farm gate in Eastern Canada; and second, to assess several methods of allocating emissions among milk and meat generated by the simulated dairy system.

\section{MATERIALS AND METHODS}

\section{Description of the LCA of Dairy Production}

The LCA was conducted over a 6 -yr period to represent the typical lifespan of dairy cows under Quebec conditions (Figure 1). The farm was located (virtually) at Napierville in the Montérégie region, Ecodistrict 541 (Table 1). To ensure that the production system was representative of typical conditions in Quebec, data were obtained from sources specific to this province. All milk production, reproductive, and cow longevity data were mean values obtained from Valacta, the Quebec dairy production center of expertise. Data pertaining to dietary composition for the livestock classes were based on expert opinion for this region [C. Bérubé (AgriAction Montérégie, Quebec, Canada) and T. deVries (University of Guelph Ontario, Canada), personal communication].

The LCA was initiated with the birth of 65 female Holstein calves $(40 \mathrm{~kg}$ ), which were offered milk replacer and concentrate for $3 \mathrm{mo}$, transitioned to a high-forage diet, composed of alfalfa/grass hay supplemented with concentrate until calving (Table 1). At 18 mo of age, heifers were bred using AI to Holstein sires. From breeding to calving, heifers were offered a corn silage- and hay-based diet supplemented with soybean meal. Sixty heifers survived (assuming a death rate of 9.6\%; USDA, $2010)$ to first calving at 27 mo of age $(596 \mathrm{~kg}$; Valacta Inc., 2010). The sex ratio of the calves born was assumed to be 51:49 male:female. The calving interval was 14 mo with a $12-$ mo lactation period (Valacta Inc., 2010). The cow replacement rate was $31 \%$, with cows

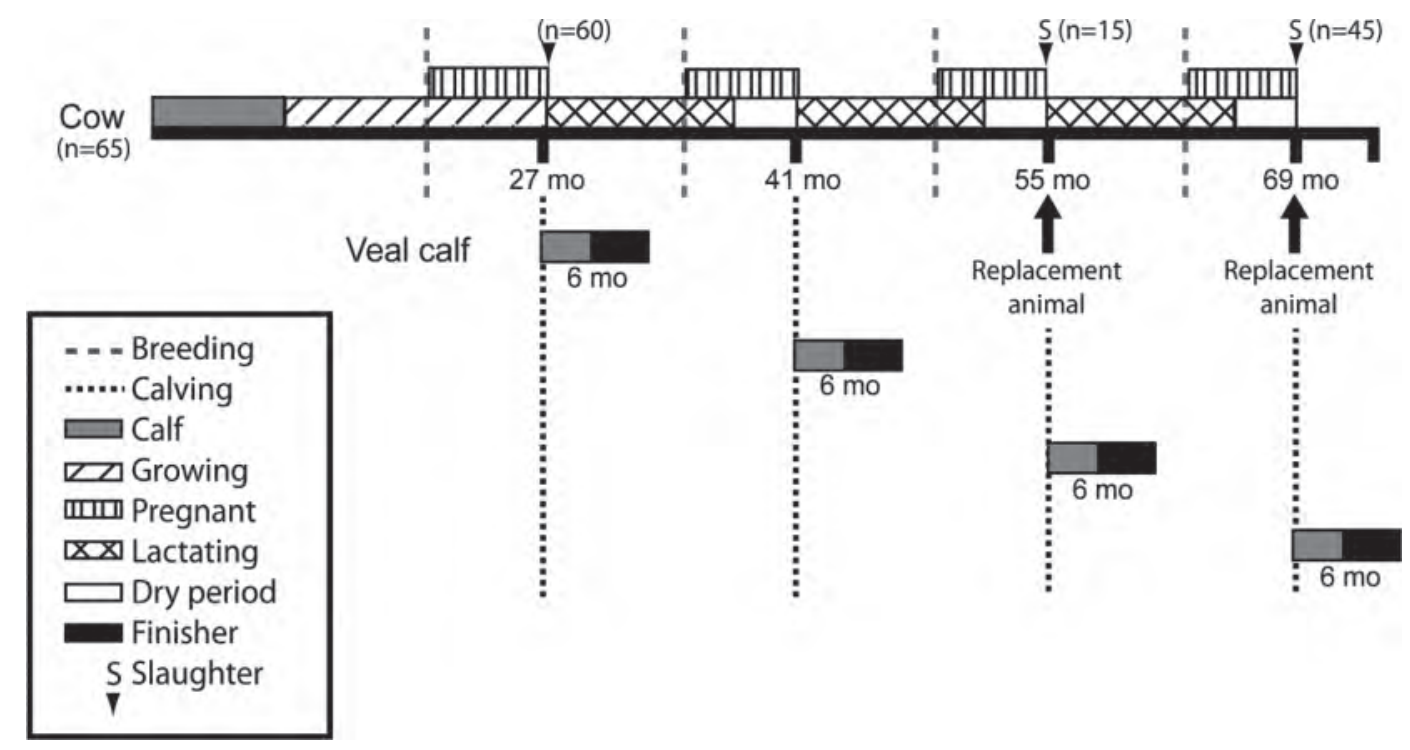

Figure 1. The livestock production cycle used in the simulated dairy system. 
Table 1. Animal categories, diet composition, and diet-specific conversion factor $\left(Y_{\mathrm{m}}\right)$ values

\begin{tabular}{|c|c|c|c|c|c|}
\hline Item & Ingredient & $\begin{array}{l}\text { Proportion } \\
\text { of diet }\end{array}$ & $\mathrm{DE}^{1}$ & $\mathrm{GEI}^{2}$ & $\mathrm{Y}_{\mathrm{m}}^{3}$ \\
\hline \multicolumn{6}{|c|}{ Replacement heifers and mature cows } \\
\hline \multirow[t]{4}{*}{$0-3$ mo of age } & Milk replacer & 70 & \multirow[t]{4}{*}{89.4} & \multirow[t]{4}{*}{25.6} & \multirow[t]{4}{*}{$0.009^{4}$} \\
\hline & Corn grain & 10.5 & & & \\
\hline & Soybean meal & 7.5 & & & \\
\hline & Mineral supplement & 1.5 & & & \\
\hline \multirow{2}{*}{$3-6$ mo of age } & Soybean meal & 1.25 & \multirow{2}{*}{59.5} & \multirow{2}{*}{70.4} & \multirow{2}{*}{0.065} \\
\hline & Mineral supplement & 0.25 & & & \\
\hline \multirow[t]{3}{*}{ 7-27 mo of age } & Corn silage & 24.39 & \multirow[t]{3}{*}{64.8} & \multirow[t]{3}{*}{145.7} & \multirow[t]{3}{*}{0.065} \\
\hline & Hay (grass/legume) & 73.17 & & & \\
\hline & Soybean meal & 2.44 & & & \\
\hline Lactation $^{5}$ & Corn silage & 27.5 & 76.6 & 330.0 & 0.055 \\
\hline \multirow{2}{*}{ Dry period } & Hay (grass/legume) & 73.17 & \multirow{2}{*}{64.8} & \multirow{2}{*}{142.1} & \multirow{2}{*}{0.065} \\
\hline & Soybean meal & 2.44 & & & \\
\hline \multicolumn{6}{|c|}{ Progeny (destined for veal) } \\
\hline \multirow[t]{2}{*}{$0-3$ mo of age } & Milk replacer & 60 & \multirow[t]{2}{*}{89.2} & \multirow[t]{2}{*}{25.6} & \multirow[t]{2}{*}{$0.012^{6}$} \\
\hline & Corn grain & 40 & & & \\
\hline $3-6.5$ mo of age & Corn grain & 100 & 88.0 & 77.9 & 0.03 \\
\hline
\end{tabular}

${ }^{1}$ Digestible energy (\% of diet DM).

${ }^{2}$ Gross energy intake (MJ/d; mean value for the livestock class).

${ }^{3} \mathrm{Y}_{\mathrm{m}}$ (conversion factor) values for each category of animal calculated according to Intergovernmental Panel on Climate Change Tier 2 recommendations.

${ }^{4} Y_{m}$ for replacer $=0 ; Y_{m}$ for concentrate $=0.03 ; Y_{m}$ of 0.009 achieved by allotting a $Y_{m}$ of 0.03 to the $30 \%$ of the diet.

${ }^{5}$ First calving at $27 \mathrm{mo}$ of age, with a calving interval of $14 \mathrm{mo}$.

${ }^{6} \mathrm{Y}_{\mathrm{m}}$ for milk replacer $=0 ; \mathrm{Y}_{\mathrm{m}}$ for concentrate $=3 ; \mathrm{Y}_{\mathrm{m}}$ of 0.012 achieved by allotting a $\mathrm{Y}_{\mathrm{m}}$ of 0.03 to the $40 \%$ of the diet.

retained for, on average, 2.75 lactations, representing the typical survival of Holstein cows in Quebec. The average milk yield was $8,530 \mathrm{~kg} / \mathrm{cow}$ per year. For this analysis, 15 cows were culled at the end of lactation 2 , with the remainder culled after lactation 3. During lactation, cows were offered a diet based on corn silage, haylage (grass/alfalfa), corn grain, and a soybean mealbased protein supplement. During the dry periods, cows were offered a predominantly forage diet similar to that offered to the bred heifers. Male calves and female calves not used as replacements were finished as grain-fed veal at $6.5 \mathrm{mo}$ of age at approximately 270 $\mathrm{kg}$, in line with common practices in Quebec. For an initial period of $3 \mathrm{mo}$, calves were offered milk replacer, as corn grain was introduced and eventually offered ad libitum. Thereafter, until slaughter, calves were offered a corn grain-based diet.

\section{Crop Production}

To account for GHG emissions associated with feed, it was assumed that all feed ingredients were produced on the farm. These included emissions associated with the establishment, management, and harvest of the grain and forage crops. Information pertaining to soil properties was derived from the Canada Soil Information System (CanSIS) data bank (Marshall et al., 1999; Table 2). Crop yields, liming, and fertilizer rates were derived from various publications produced by Centre de référence en agriculture et agroalimentaire du Qué-

Table 2. Simulated farm information

\begin{tabular}{ll}
\hline Item & Description \\
\hline Ecodistrict & \\
Ecozone & 541 \\
Province & Mixedwood Plains \\
Present tillage $_{\text {Soil texture }^{1}}$ & Quebec \\
Precipitation $^{1}(\mathrm{~mm})$ & Reduced/minimum till \\
Potential evapotranspiration $^{1}(\mathrm{~mm})$ & Fine \\
${\text { Total yearly farm } \text { area }^{2}(\mathrm{ha})}$ & 559 (May-October) \\
& 529 (May-October) \\
\hline
\end{tabular}

${ }^{1}$ Data sourced from the Canada Soil Information System (CanSIS) data bank (Marshall et al., 1999).

${ }^{2}$ Total area requirements for the life cycle prorated over the entire life cycle. 
bec (CRAAQ, 2010; Table 3). Where soybean meal was offered, it was assumed that the crop was grown on farm, transported $(60 \mathrm{~km})$ off-farm for processing, with the meal then returned to the farm for inclusion in the dietary rations. The allocation ratio between soybean meal and oil was estimated according to the guidelines of the International Dairy Federation (IDF, 2010) to ensure that only emissions associated with the meal were included. The oil-to-meal ratio was $17.5: 80$, with a $2.5 \%$ moisture and shrinkage loss.

\section{Manure Handling System}

During lactation, cows were housed in individual tie-stalls, bedded with straw from the cereals grown for supplementary concentrate. Dry cows were group housed in straw-bedded pens. Replacement female calves from birth to calving, as well as veal calves, were group housed in straw-bedded pens. The accumulated solid manure was stockpiled over the year and applied in the fall to the land used to grow the feed crops. Rates of manure application were determined by the individual crop requirements (CRAAQ, 2010). In this study, the application of livestock manure was sufficient to meet the crop $\mathrm{N}$ requirements, so no synthetic fertilizer was applied. Additionally, as the amount of manure generated was in excess of requirement, it was assumed that this manure could be used to meet the fertilizer requirements on neighboring farms (emissions from transport, therefore, negligible). Thus, a $\mathrm{CO}_{2}$ offset was generated accounting for emissions associated with producing the equivalent amount of synthetic fertilizer. Emission factors for manure are reported in Table 4.

\section{Use of Holos Software Model to Quantify GHG Emissions}

The GHG emissions associated with dairy production under Canadian conditions were determined using Holos, a software model developed by Agriculture and Agri-Food Canada (Ottawa, ON, Canada; Little et al., 2008; http:/ /www.agr.gc.ca/holos-ghg), as described by Beauchemin et al. (2010). Briefly, Holos is a whole-farm model and software program that estimates whole-farm GHG emissions based on information entered for individual farms. It is an empirical model with yearly time steps, based broadly on Intergovernmental Panel on Climate Change (IPCC) methodologies, but with algorithms modified to reflect Canadian conditions and farming practices.

Holos calculates GHG emissions from both on- and off-farm processes in dairy systems. In this study, the system boundary was defined as the farm gate; thus, GHG emissions and removals arising from both onfarm processes and the off-farm production of inputs (excluding capital goods; i.e., the production of barns, machinery, milking equipment, among other items) were included (Figure 2). The farm gate is the most commonly used system boundary for dairy because 78 to $83 \%$ of dairy sector emissions in North America, Europe, and Oceania are generated on farm (Gerber et al., 2010). Thus, emissions from the transport, processing, and consumption of products after they leave the farm were not included. Emissions quantified in the analysis include (1) $\mathrm{CH}_{4}$ arising from enteric fermentation and manure; (2) $\mathrm{N}_{2} \mathrm{O}$ from soils, manure, growing crops, and $\mathrm{N}$ leaching, runoff, and volatilization; and (3) $\mathrm{CO}_{2}$ from soil carbon change, fuel use, liming of crops, and off-farm processes involved in the production of farm

Table 3. Crop factors used in dairy emissions

\begin{tabular}{|c|c|c|c|c|c|c|}
\hline Item & Corn grain & Corn silage & Soybean & Barley grain & $\begin{array}{c}\text { Grass/legume } \\
\text { hay }\end{array}$ & $\begin{array}{c}\text { Grass/legume } \\
\text { haylage }\end{array}$ \\
\hline Field yield (kg/ha) & 8,300 & 35,000 & 2,700 & 3,100 & 5,020 & 5,020 \\
\hline Manure $\mathrm{N}$ application rate $(\mathrm{kg} / \mathrm{ha})$ & 160 & 160 & 20 & 80 & 0 & 0 \\
\hline Herbicide application & Yes & Yes & Yes & Yes & No & No \\
\hline DM content $(\mathrm{g} / \mathrm{kg})$ & 850 & 300 & 860 & 880 & 870 & 420 \\
\hline Above-ground residue $\mathrm{N}(\mathrm{kg}$ of $\mathrm{N} / \mathrm{kg}$ ) & 0.005 & 0.013 & 0.006 & 0.007 & 0.015 & 0.015 \\
\hline Above-ground residue ratio & 0.38 & 0.08 & 0.45 & 0.47 & 0.10 & 0.10 \\
\hline Below-ground residue ratio & 0.15 & 0.20 & 0.25 & 0.15 & 0.50 & 0.50 \\
\hline Total yearly area required ${ }^{1}(\mathrm{ha})$ & 7.39 & 7.32 & 12.38 & 0.08 & 15.89 & 27.86 \\
\hline Lime application rate $\left(\mathrm{kg}\right.$ of $\left.\mathrm{CaCO}_{3} / \mathrm{ha}\right)$ & 500 & 500 & 200 & 300 & 0 & 0 \\
\hline Length of perennial stand (yr) & $\mathrm{NA}^{2}$ & NA & NA & NA & 5 & 5 \\
\hline
\end{tabular}

${ }^{1}$ Total area requirements for the life cycle prorated over the life cycle.

${ }^{2} \mathrm{NA}=$ not applicable, 
Table 4. Sources of greenhouse gas (GHG) emissions, equation or emission factor (EF) used, and reference source

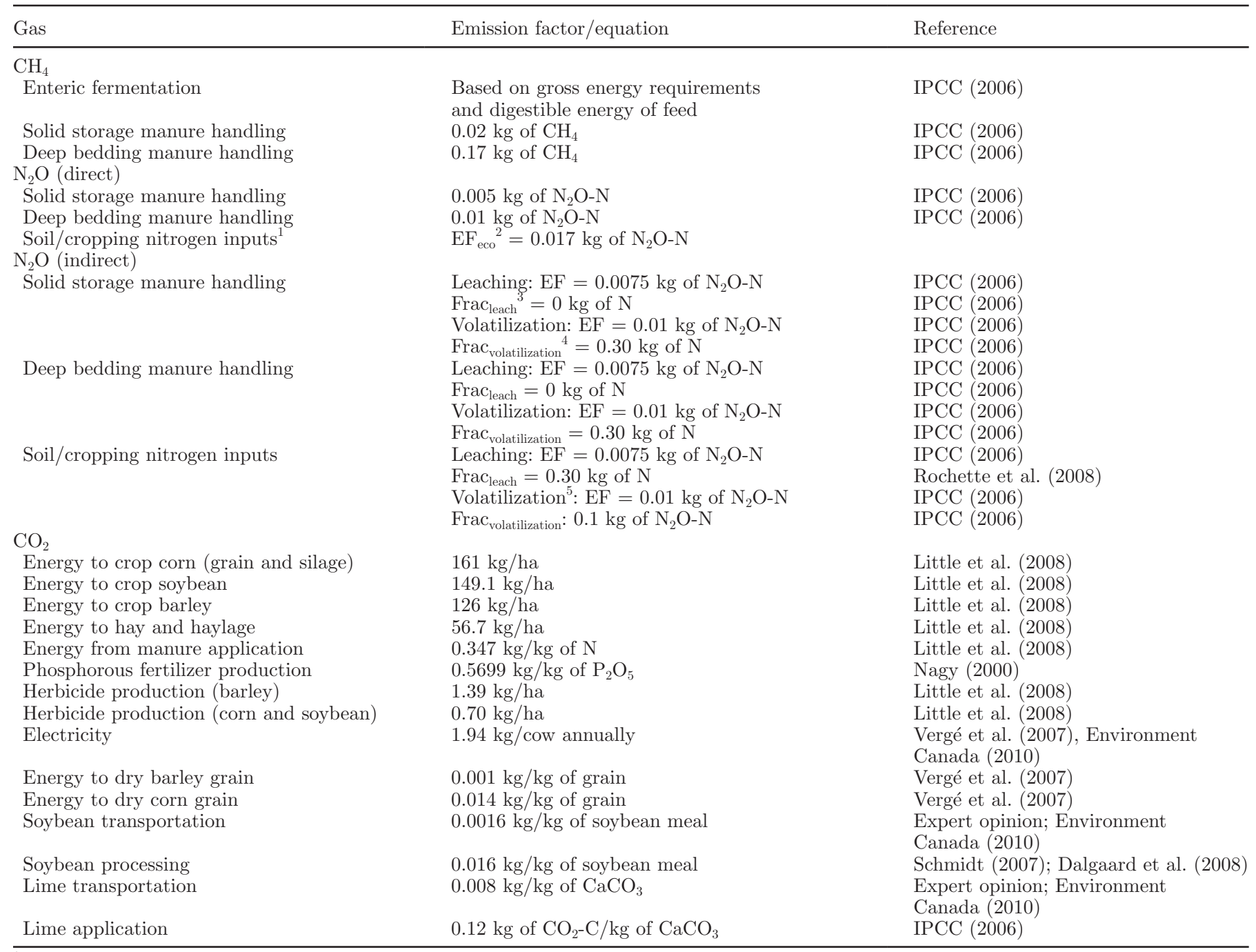

${ }^{1}$ Includes land applied manure, crop residue, synthetic nitrogen fertilizer, and mineralized N.

${ }^{2}$ Emission factor for the ecodistrict.

${ }^{3}$ Leaching fraction.

${ }^{4}$ Volatilization fraction.

${ }^{5}$ Indirect emissions due to volatilization are only calculated based on nitrogen inputs from land applied manure and synthetic nitrogen fertilizer.

inputs. All gases were expressed on a $\mathrm{CO}_{2}$-equivalent $\left(\mathrm{CO}_{2} \mathrm{Eq}\right)$ basis, with Holos updated to include the global warming potentials (GWP) recommended by IPCC (2007): $25 \mathrm{~kg}$ of $\mathrm{CO}_{2} \mathrm{Eq} / \mathrm{kg}$ of $\mathrm{CH}_{4}$ and $298 \mathrm{~kg}$ of $\mathrm{CO}_{2} \mathrm{Eq} / \mathrm{kg}$ of $\mathrm{N}_{2} \mathrm{O}$.

Livestock $\mathrm{CH}_{4}$ emissions were estimated according to a modified IPCC Tier 2 approach. Daily net energy (NE) requirements were estimated from NE use in maintenance, growth, activity, pregnancy, and lactation. The GE intake required to meet these NE needs was calculated taking into account the varying digestibility of the dietary ingredients. Emissions of $\mathrm{CH}_{4}$ were then calculated as a percentage of $\mathrm{GE}$ intake using diet-specific conversion factors $\left(\mathbf{Y}_{\mathbf{m}}\right)$. For nonlactating females greater than 3 mo of age, the $\mathrm{Y}_{\mathrm{m}}$ was set at 0.065 due to the high proportion of forage in diets (Table 1). Despite the high proportion of forage in the diet, a $Y_{m}$ value from the upper end of the IPCC range of 0.055 to 0.075 was not chosen. This is due to the inclusion of supplementary soybean meal and corn silage, with the latter being defined as starch-rich forage relative to grass/alfalfa hay. For lactating cows, where the diet contained more concentrates, the $\mathrm{Y}_{\mathrm{m}}$ was set at the lowest end of the IPCC range at 0.055 . For grain-fed veal calves the $Y_{m}$ was set to 0.012 for the first $3 \mathrm{mo}$ of life. This figure was calculated from the relative contributions of milk, where the $Y_{m}$ was 0 , and grain where the $Y_{m}$ was 0.03 and calculating the aver- 


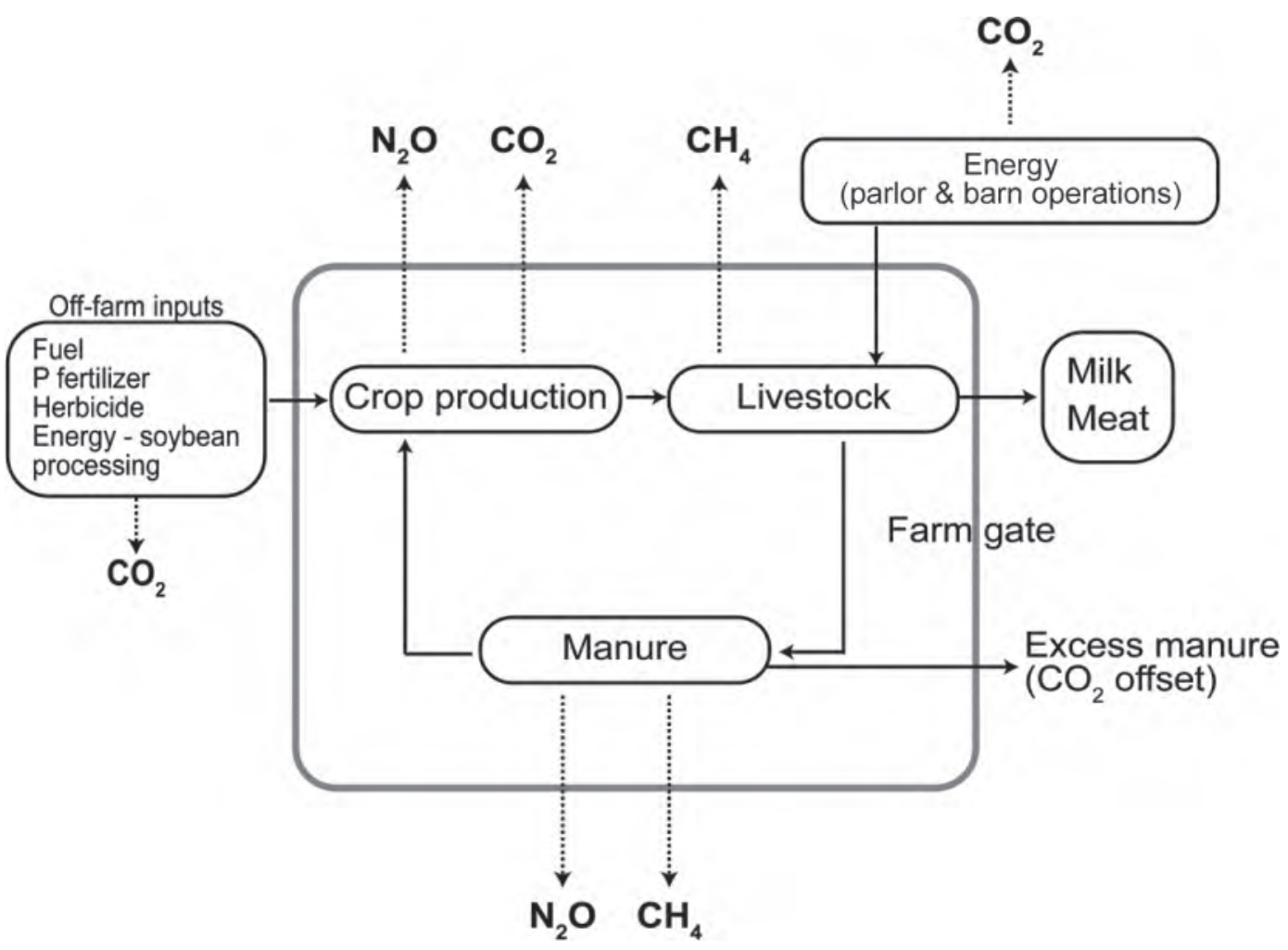

Figure 2. On- and off-farm emission sources in the simulated dairy system.

age $Y_{m}$ for the period. A $Y_{m}$ of 0.03 was assigned for the subsequent $3.5 \mathrm{mo}$, where a grain-only diet was offered.

Emissions of $\mathrm{CH}_{4}$ from manure were estimated using Holos, based on the volatile solids produced (IPCC, 2006), accounting for diet digestibility and GE intake. Volatile solid production is multiplied by the $\mathrm{CH}_{4}$-producing capacity of the animal ( 0.24 for dairy animals; IPCC, 2006) and the $\mathrm{CH}_{4}$ conversion factor specific to the manure handling system used (Table 4). Manure N was estimated from DMI and the $\mathrm{CP}(6.25 \times \mathrm{N})$ content of the diet, and $\mathrm{N}$ retention of the animals based on IPCC (2006) and NRC (2001). Manure N content was multiplied by an emission factor for the manure solid storage handling system to calculate direct $\mathrm{N}_{2} \mathrm{O}$ emissions (IPCC, 2006). The amount of manure $\mathrm{N}$ from solid storage was adjusted for losses during storage and this was then applied to the land.

Emissions of $\mathrm{N}_{2} \mathrm{O}$ from soils were calculated based on $\mathrm{N}$ inputs, with modifications for soil texture, tillage, topography, and climate. Sources of N included landapplied manure, crop residue decomposition, and net $\mathrm{N}$ mineralization estimated from net change in soil carbon (assumed to be zero in this instance). Soil-derived $\mathrm{N}_{2} \mathrm{O}$ emission was calculated from total $\mathrm{N}$ inputs using Canada-specific algorithms for estimating national GHG emissions (Rochette et al., 2008). Indirect $\mathrm{N}_{2} \mathrm{O}$ emissions from $\mathrm{N}$ leaching, runoff, and volatilization were estimated from assumed fractions of $\mathrm{N}$ lost from $\mathrm{N}$ inputs and the IPCC (2006) emission factor. It was assumed that cropland management had been unchanged for several decades; hence, the carbon flux was negligible and a steady state $\mathrm{C}$ flux was assumed.

The $\mathrm{CO}_{2}$ emissions from burning of fossil fuels in field operations, grain drying, transport of inputs, production of herbicides/insecticides, electricity, and processing of soybeans to oil and meal were also included in this analysis (Table 4). For electricity, Quebec specific coefficient values were used in place of the Canadian average values reported for Holos previously. Emissions of $\mathrm{CO}_{2}$ associated with the transport and application of lime to cropland were also included (IPCC, 2006; Environment Canada, 2010).

\section{Functional Unit}

In LCA studies, the functional unit can be defined as the quantified product of the system, and is the reference unit to which GHG emissions are expressed (Weidema et al., 2004). As dairy systems generate multiple products, the use of more than 1 functional unit is appropriate to allow for accurate interproduct comparisons. In this study, emissions were expressed in 
several ways, besides reporting total $\mathrm{CO}_{2} \mathrm{Eq}$ emitted. Emissions were expressed per kilogram of FPCM at the farm gate, using the following equation of the IDF (IDF, 2010):

$$
\begin{aligned}
& \mathrm{FPCM}(\mathrm{kg} / \mathrm{yr})=\text { production }(\mathrm{kg} / \mathrm{yr}) \times(0.1226 \\
& \times \text { fat } \%+0.0776 \times \text { true protein } \%+0.2534)
\end{aligned}
$$

The average milk production of cows was $8,530 \mathrm{~kg} / \mathrm{yr}$, with $3.85 \%$ milk fat and $3.03 \%$ true protein (converted from CP reported by Valacta Inc. to true protein) contents, reflecting averages for Holstein cows in Quebec (Valacta Inc., 2009).

Additionally, emissions were expressed per kilogram of BW for liveweight and carcass weight (calculated as 0.60 liveweight). Third, emissions were expressed per kilogram of energy, providing a common denominator between coproducts. The energy content of milk was calculated as $3.12 \mathrm{MJ} / \mathrm{kg}$ according to equation 2-16 of the NRC (2001):

$$
\begin{gathered}
\mathrm{NE}(\mathrm{MJ})=0.0929 \times \text { fat } \%+0.0563 \\
\times \text { true protein } \%+0.192 .
\end{gathered}
$$

The energy content of meat was set at $12.18 \mathrm{MJ} /$ kg (USDA, 2011). Fourthly, emissions were expressed per kilogram of protein. Similar to energy, protein is a common denominator for milk and meat. True protein content was set at $3.03 \%$ for milk (Valacta Inc., 2009) and $17.32 \%$ for meat (USDA, 2011). Emissions were expressed also on a per-hectare basis, with the land area based on the amount of crop and forage land needed to support livestock nutritional requirements.

\section{Coproduct Allocation}

Dairy systems generate several saleable products, so the GHG emissions should ideally be allocated across the coproducts. Meat from male calves, female calves in excess of replacement requirements, and culled cows is an inevitable and valuable coproduct of dairy production. This study assessed several allocation methodologies, in addition to one where $100 \%$ of GHG emissions generated were assigned to milk.

According to the ISO (2006; standard 14044), several procedures exist for the allocation of GHG to meat and milk. These include (1) system expansion (i.e., GHG emissions are assigned to dairy beef based on a parallel traditional beef production system, which assumes that meat from dairy production displaces an equal amount of beef production), (2) allocation on the basis of a cause-effect/physical relationship between the prod- ucts, and (3) allocation on the basis of economic value. From the ISO (2006) recommendations, economic and physical allocation were chosen. For economic allocation, the price of milk was set at $\$ 0.75$ per liter of crude milk (5-yr average price in Quebec; Canadian Dairy Information Centre, 2011b), and the average price of meat was set at $\$ 4.06 / \mathrm{kg}$ carcass for veal calves and at $\$ 1.32 / \mathrm{kg}$ carcass for culled cows (5-yr averages; Agriculture and Agri-Food Canada, 2011). Physical allocation was based on the physiological feed requirements of the animal to produce meat and milk using the following equation recommended by the IDF (2010):

$$
\mathrm{AF}=1-5.7717 \times \mathrm{R},
$$

where $A F=$ allocation factor and $\mathrm{R}=\mathrm{M}_{\text {meat }} / \mathrm{M}_{\text {milk }}$, where $\mathrm{M}_{\text {meat }}=$ sum of liveweight of all animals sold, including calves and culled cows, and $\mathrm{M}_{\text {milk }}=$ sum of milk sold corrected for true protein and fat content. This procedure is based on physical causality accounting for the feed energy demand needed for producing milk and meat, respectively. This study used 2 scenarios based on this equation: (1) IDF default, where the allocation factor was determined using the default value of 0.025 $\mathrm{kg}$ of meat $/ \mathrm{kg}$ of milk to yield an allocation of $14.4 \%$ to meat and $85.6 \%$ to milk; and (2) IDF specific, where the allocation factor was determined using the meat and milk yield values generated by the simulated farm $(\mathrm{R}=0.046)$, yielding an allocation of $26.6 \%$ to meat and $73.4 \%$ to milk.

Emissions were also allocated between the dairy and veal animals. For this, all emissions from veal calves, directly or indirectly, were separated from those associated with the dairy cows from birth to slaughter.

\section{RESULTS AND DISCUSSION}

The GHG intensity for this nongrazing dairy system with no allocation to meat was $0.92 \mathrm{~kg}$ of $\mathrm{CO}_{2} \mathrm{Eq} / \mathrm{kg}$ of FPCM (Table 5), well within the range of values reported for dairy LCA in recent literature (Rotz et al., 2010; Flysjö et al., 2011b; Kristensen et al., 2011). Rotz et al. (2010), reporting the carbon footprint of a nongrazing North American dairy system somewhat comparable to ours, found a considerably lower GHG intensity of $0.69 \mathrm{~kg}$ of $\mathrm{CO}_{2} \mathrm{Eq} / \mathrm{kg}$ of ECM using the DairyGHG software model. However, these authors considered the contribution of carbon sinks and sources in their analysis, which is in contrast with the current study. In the current study, carbon flows were assumed to be at a steady state; thus, loss and sequestration of carbon, in addition to $\mathrm{CO}_{2}$ generated from animal respiration, were not included. Removing biogenic carbon 
from the analysis of Rotz et al. (2010) would increase the GHG intensity by $0.3 \mathrm{~kg}$ to $0.99 \mathrm{~kg}$ of $\mathrm{CO}_{2} \mathrm{Eq} / \mathrm{kg}$ of ECM. Corrected to $4 \%$ milk fat in accordance with IDF guidelines, the GHG intensity would be $1.07 \mathrm{~kg}$ of $\mathrm{CO}_{2}$ $\mathrm{Eq} / \mathrm{kg}$ of FPCM. Additionally, as this figure is based on $91 \%$ of the emissions being allocated to milk, the GHG intensity would further increase to $1.17 \mathrm{~kg}$ of $\mathrm{CO}_{2}$ $\mathrm{Eq} / \mathrm{kg}$ of FPCM if $100 \%$ of the emissions generated by the dairy system were assigned to milk. Our estimate of GHG intensity was also lower than values reported by Phetteplace et al. $\left(2001 ; 1.09 \mathrm{~kg}\right.$ of $\mathrm{CO}_{2} \mathrm{Eq} / \mathrm{kg}$ of milk) and Capper et al. (2009; $1.35 \mathrm{~kg}$ of $\mathrm{CO}_{2} \mathrm{Eq} / \mathrm{kg}$ of milk corrected to $1.44 \mathrm{~kg}$ of $\mathrm{CO}_{2} \mathrm{Eq} / \mathrm{kg}$ of $\mathrm{FPCM}$ ) for various US farms.

Results from various LCA can be compared only with caution because of inevitable differences among such studies as illustrated above. Although the broad principles, as outlined by the ISO (2006) and the British Standards Institute (BSI, 2008), may be common to all LCA, the specific methodologies and assumptions used to calculate GHG intensity often vary greatly. For example, in our study, the algorithms and emissions factors used to calculate relative gaseous contributions were tuned to Canadian farming systems, and may not be directly applicable to other geographical regions. Differences in production parameters, management regimens and sources included can also lead to discrepancies between LCA. All of these factors need

Table 5. Life-cycle analysis greenhouse gas emission and production results

\begin{tabular}{lc}
\hline & $\begin{array}{c}\text { Emissions } \\
\text { Item }\end{array}$ \\
\hline Total emissions $\left.\mathrm{CO}_{2} \mathrm{Eq}\right)$
\end{tabular}

to be considered in extrapolating the results of such assessments.

Although the nongrazing nature of the simulated farm in our study is typical for Eastern Canada and other areas of North America, pastoral-based dairying is also commonplace. Although nongrazing systems require additional inputs related to cropping, the GHG intensity in our study was still lower than those reported for pastoral systems $\left(1.3,1.1\right.$, and $1.0 \mathrm{~kg}$ of $\mathrm{CO}_{2} \mathrm{Eq} /$ $\mathrm{kg}$ of ECM, respectively) by Casey and Holden, (2005), Beukes et al. (2011), and Flysjö et al. (2011b). This difference may be attributed to several factors, but the most important may be the effect of the diet composition, which strongly influences enteric $\mathrm{CH}_{4}$ production (Johnson and Johnson, 1995; Moss et al., 2000). In our study, lactating cows received cereal grains totaling $43 \%$ of the diet, with corn silage accounting for a further $22.5 \%$. Diets high in readily fermentable carbohydrates reduce enteric $\mathrm{CH}_{4}$ production relative to that in high-fiber pastoral diets, due to their greater propionic acid production and lower $\mathrm{pH}$ in the rumen and the subsequent inhibitory effects on methanogenesis (Moss et al., 2000). Additionally, the level of animal performance directly influences GHG intensity, evidenced by the milk yield per cow (yearly) in our study $(8,170 \mathrm{~kg}$ of FPCM) being higher than that reported by Flysjö et al. (2011b; 4,118 kg of ECM) for pastoral-based dairy LCA. This may be partially accounted for by the higher starch content of the offered diet in our study relative to grass-only diets.

Beyond quantifying the GHG intensity of milk production, this assessment also identified the various sources of emissions and quantified their relative contributions - an important function of LCA that highlights areas of the production system that warrant the most attention and where largest reductions are possible. In the current assessment, $\mathrm{CH}_{4}$ accounted for $56 \%$ of total GHG emissions (Figure 3). Of this, $86 \%$ was derived directly from enteric fermentation of feed in the gastrointestinal tract. Similarly, Rotz et al. (2010), Flysjö et al. (2011b), and Kristensen et al. (2011) also reported $\mathrm{CH}_{4}$ to be the predominant contributor to the total GHG emissions, with enteric fermentation the primary source in each instance (76, $94-98$, and $85 \%$, respectively). It is, therefore, apparent that abatement of $\mathrm{CH}_{4}$, particularly enterically derived $\mathrm{CH}_{4}$, would result in the most significant reduction in GHG emissions from both confinement and pasturebased dairy production systems. Emissions of $\mathrm{N}_{2} \mathrm{O}$ were also significant, accounting for $40 \%$ of the total GHG, a value similar to that reported by Rotz et al. (2010) for a confined dairy system (37.6\%; Figure 3$)$. The relatively large output of $\mathrm{N}_{2} \mathrm{O}$ in the current study reflects the high $\mathrm{N}$ inputs required for producing all feeds on 
the farm. However, the value for our simulated farm may actually underestimate $\mathrm{N}_{2} \mathrm{O}$ emissions on commercial farms. This may also have the implication that the relative proportions of the other GHG are partially overestimated. In the LCA, manure was applied at a rate to meet crop nutrient requirements only, whereas on some farms, synthetic fertilizer and manure are applied at rates exceeding crop requirements, resulting in additional direct and indirect $\mathrm{N}$ losses. In many parts of Canada, fertilizer application rates are not highly regulated; thus, nutrients may sometimes be overapplied, especially where excess amounts of manure are available. In general, given the large proportion of $\mathrm{N}_{2} \mathrm{O}$ generated in this assessment, implementing practices to improve $\mathrm{N}$ use efficiency on dairy farms would help lower the carbon footprint of milk.

Assessment of the individual livestock groups indicated that lactating animals were the predominant source of GHG emissions, contributing $64 \%$ to the total (Figure 4). Conversely, the contribution of progeny intended for veal production was negligible (3\% of the total), and animals less than 12 mo of age contributed only $10 \%$ of the total system emissions. The incomplete development of the rumen at this young age and lower GE intake, resulting in lower $\mathrm{CH}_{4}$ emissions, may account largely for this relatively low value. However, consideration of the $Y_{m}$ value chosen also affected the total GHG emitted. Given this low contribution, mitigation strategies aimed at these animals would

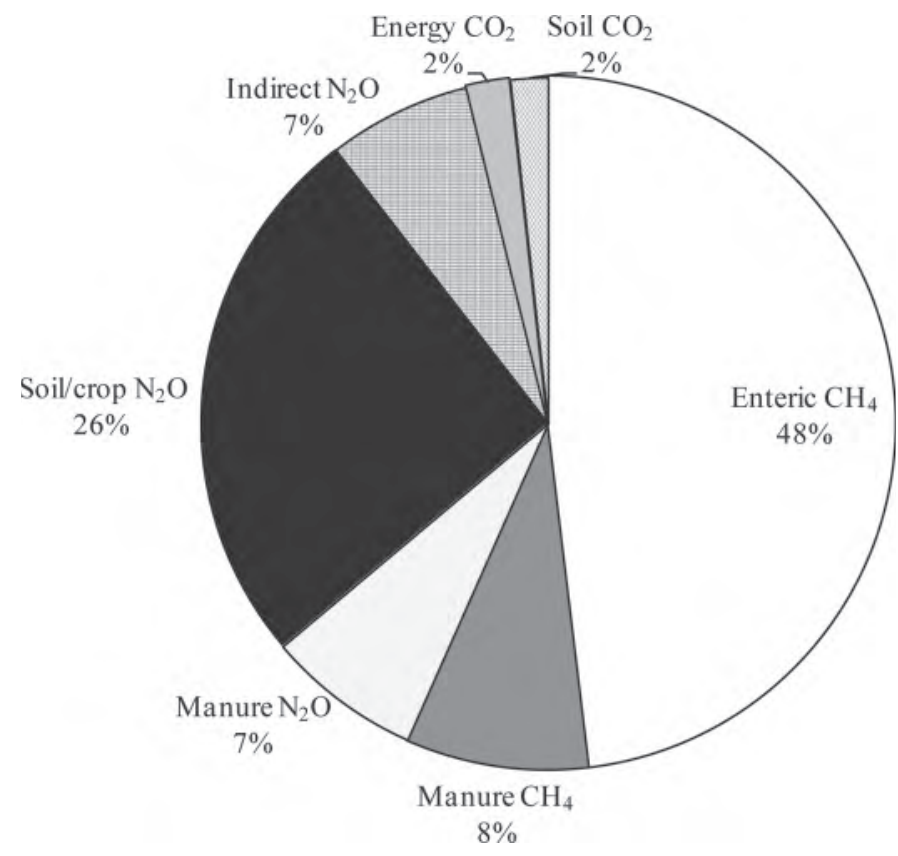

Figure 3. Relative proportions of greenhouse gas (GHG) emissions from the dairy production cycle simulated over a 6 -yr cycle.

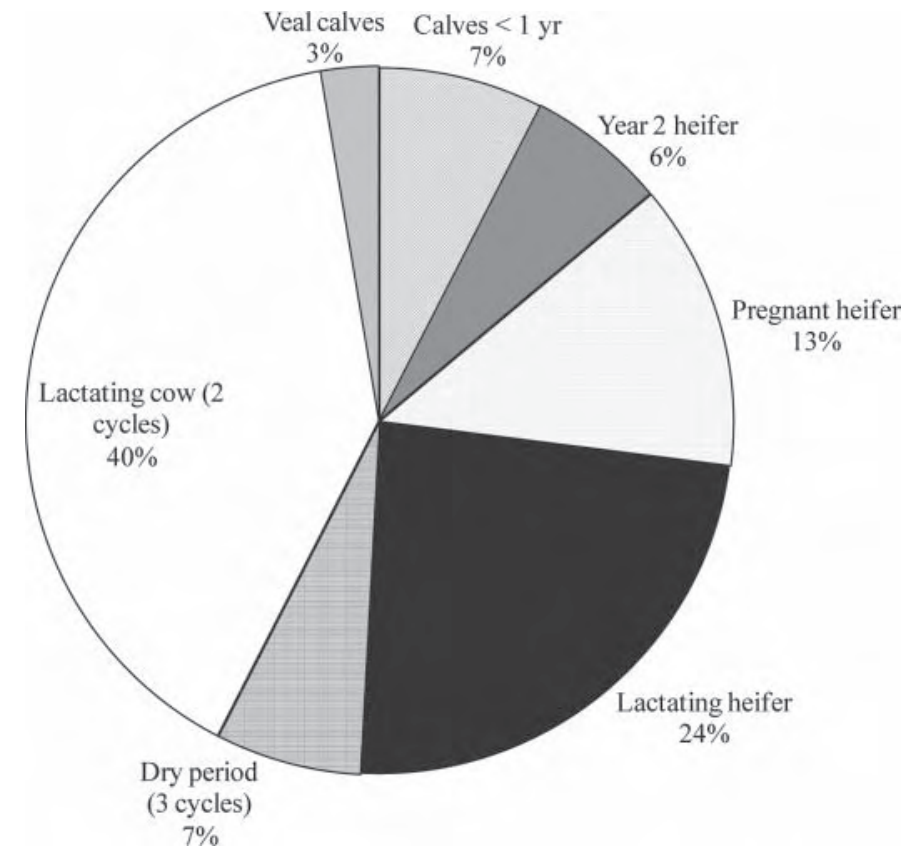

Figure 4. Relative contribution of the livestock groups to the total greenhouse gas (GHG) emissions over the 6-yr cycle.

not appreciably reduce total GHG emissions from dairy production systems. Assessment of the relative proportion of GHG emissions for the lactating versus nonlactating animals showed enteric $\mathrm{CH}_{4}$ emissions for the former group to be $10 \%$ higher ( 51 vs. $41 \%$; Figures 5 and 6 , respectively). A notable difference in manure $\mathrm{CH}_{4}$ output between these livestock classes was also observed, accounting for 2 versus 19\% of total GHG emissions. The relative proportions of the other gases were not different among livestock groups.

\section{Coproduct Allocation}

Although the ISO (2006) recommends avoiding allocation when possible, often it cannot be avoided where biological processes are involved. Dairy farms produce both milk and meat (accounting for $57 \%$ of the global meat production; Gerber et al., 2010); thus, the allocation of the gaseous burden is warranted. Our LCA showed that the choice of allocation procedure had a significant effect on GHG intensity, with 73 to $97 \%$ of emissions being assigned to milk depending on the allocation procedure (Table 6). The highest allocation to milk was observed with the dairy versus veal animal scenario (97\%), whereby all emissions associated with the production of veal calves were separated from those arising from the dairy cows and replacement heifers. The low allocation to the veal animal reflected both low $\mathrm{CH}_{4}$ emissions from the animals and low emissions from 


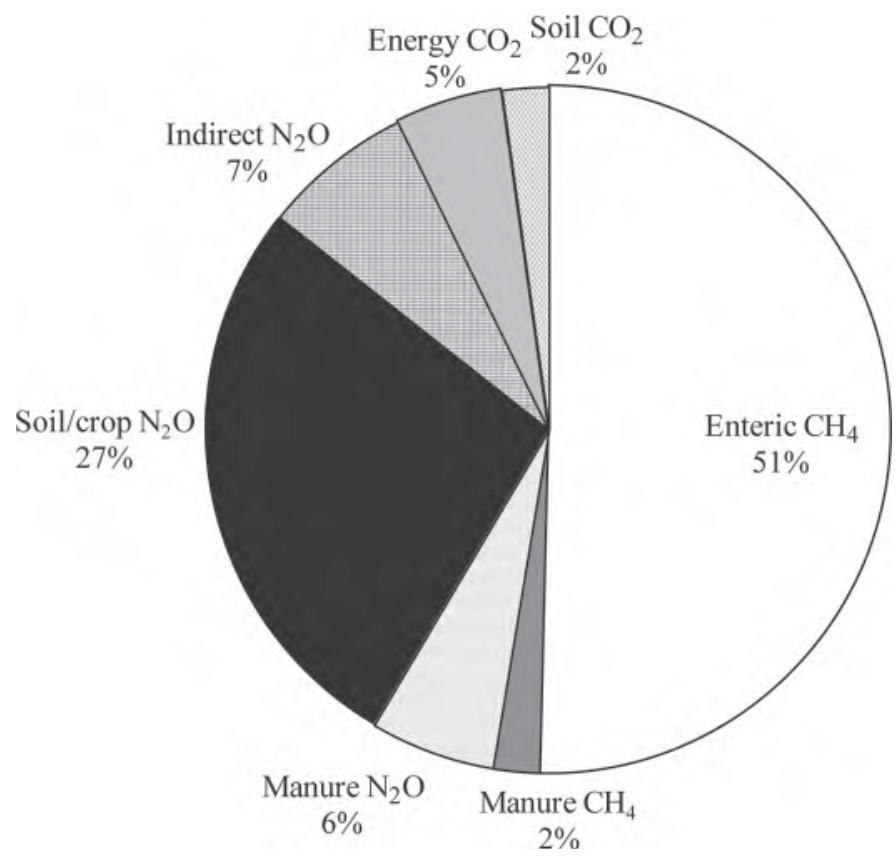

Figure 5. Relative proportion of greenhouse gas emissions from the lactating animals over the 6-yr cycle.

the minimal inputs required to maintain these animals for a short time. Economic allocation resulted in $91 \%$ of emissions being assigned to milk, a value similar to those of Cederberg and Stadig (2003) and Thomassen et al. (2008), who reported that $92 \%$ of the emissions were allocated to milk on the basis of economics. Economic allocation has the advantage of a common unit $(\$ / \mathrm{kg})$ for all products, but it is subject to fluctuations in commodity prices over time. To overcome this variability in our study, commodity prices were averaged over a 5 -yr period. Furthermore, the allocation of emissions on the basis of economics is the procedure favored by the BSI (2008). The allocation of emissions to milk was lowest when we used the IDF equation, which accounts for

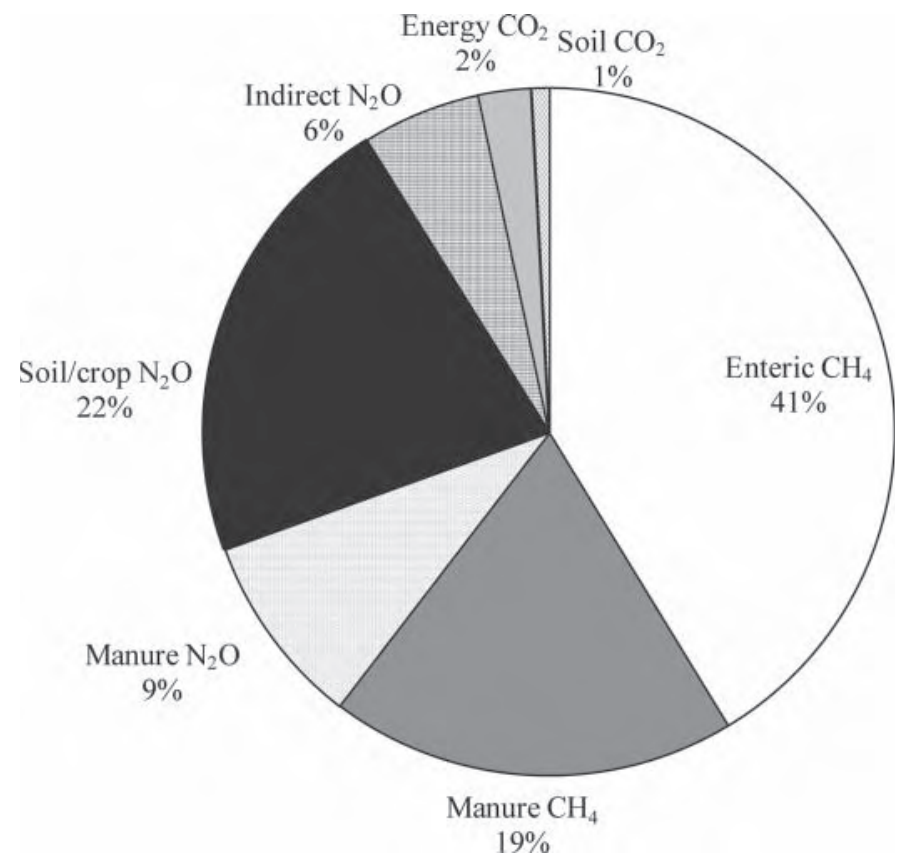

Figure 6. Relative proportion of greenhouse gas emissions from the nonlactating animals over the 6-yr cycle.

the feed energy required to produce the mass of meat and milk. Two scenarios were used: the first used the default meat-to-milk ratio recommended by the IDF (14.4:85.6), allocating $83 \%$ of emissions to milk. This allocation is similar to that reported by Flysjö et al. (2011a) for Swedish dairy production. In the second scenario, the actual meat-to-milk ratio produced on the simulated farm (26.6:73.4) resulted in $78 \%$ of emissions being allocated to milk.

In addition to the allocation methods discussed above, the ISO (2006) also recommend system expansion as a potential means of allocating coproduct emissions. Although often applicable, we did not assess this approach, which has particular merit when dairy produc-

Table 6. Greenhouse gas emissions as affected by allocation method

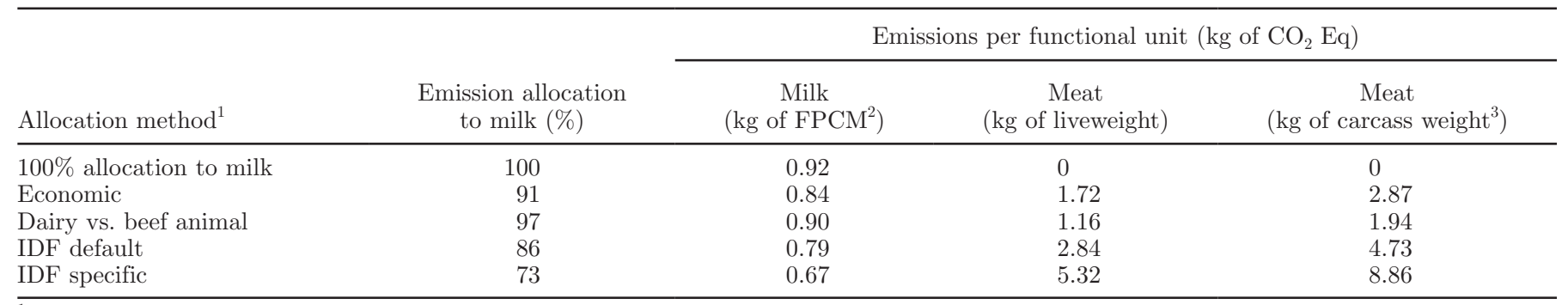

${ }^{1}$ Economic $=$ based on 5 -yr average of milk and meat prices; dairy vs. beef = emissions allocated; IDF default = International Dairy Federation equation using default meat-to-milk ratio; IDF specific = International Dairy Federation equation using meat-to-milk ratio calculated from model farm simulation.

${ }^{2}$ Fat- and protein-corrected milk.

${ }^{3}$ Calculated as 0.60 of liveweight. 
tion is relied upon to meet demands for beef. However, in Canada the primary source of beef is its large herd of nondairy cattle, tailored to meet particular market demands and consisting mainly of traditional beef breeds such as Aberdeen Angus and Hereford. Given that market demands are met primarily by this beef herd, increases in beef output from dairying may not significantly reduce emissions from the nondairy herd. Indeed, it is reported globally that beef production is increasing (FAO, 2008), further limiting system expansion as an option for coproduct allocation.

The variability between allocation procedures was not unexpected, given results from previous studies (Cederberg and Stadig, 2003; Casey and Holden, 2005; Flysjö et al., 2011a). Given that each allocation procedure infers specific advantages and disadvantages, the most appropriate choice of procedure will be determined by the needs and availability of data of any particular study.

\section{Implications}

In addition to quantifying the GHG intensity of dairy production in Eastern Canada for potential inventory purposes, this study also established a baseline scenario for dairy production against which potential mitigation strategies may be compared. It is here that the main value of LCA may lie. The evaluation of mitigation strategies can be considered most accurate when the assumptions, in particular the algorithms and the emissions factors used in the assessment, are constant. In the current study, lactating animals had the largest contribution to the total GHG emissions; thus, research efforts are best served focusing on this livestock category. Numerous mitigation strategies have been previously reviewed by Boadi et al. (2004), Grainger and Beauchemin (2011), and present potential options for $\mathrm{CH}_{4}$ abatement. Such strategies may include increasing concentrates or lipids in diets, improving reproductive efficiency, and improving manure management.

Although the primary focus of such an approach to dairy LCA is GHG emissions, it is necessary to evaluate also the effects of mitigation strategies on animal performance. For example, increasing the proportion of concentrates in the diet may reduce enteric $\mathrm{CH}_{4}$ emission; however, above a certain level, it may reduce milk fat content (Sutton and Morant, 1989). Practices that mitigate GHG emissions but have negative effects on milk yield, fat and protein contents, DMI, or feed efficiency are unlikely to be adopted. As LCA include all production data, the net effects on these parameters may also be evaluated. Thus, the level of adoption of GHG mitigation strategies by dairy farmers in Eastern
Canada will be directly related to their effects on animal performance and profitability.

\section{REFERENCES}

Agriculture and Agri-Food Canada. 2011. Red meat market information. Accessed Mar. 23, 2011. http://www.agr.gc.ca/redmeat-vianderouge/pri_eng.htm\#cattle.

Beauchemin, K. A., H. H. Janzen, S. M. Little, T. A. McAllister, and S. M. McGinn. 2010. Life cycle assessment of greenhouse gas emissions from beef production in western Canada: A case study. Agric. Syst. 103:371-379.

Beauchemin, K. A., M. Kreuzer, F. O'Mara, and T. A. McAllister. 2008. Nutritional management for enteric methane abatement: A review. Aust. J. Exp. Agric. 48:21-27.

Beukes, P. C., P. Gregorini, and A. J. Romera. 2011. Estimating greenhouse gas emissions from New Zealand dairy systems using a mechanistic whole farm model and inventory methodology. Anim. Feed Sci. Technol. 166-167:708-720.

Boadi, D., C. Benchaar, J. Chiquette, and D. Massé. 2004. Mitigation strategies to reduce enteric methane emissions from dairy cows: Update review. Can. J. Anim. Sci. 84:319-335.

BSI (British Standards Institute). 2008. Specification for the assessment of life cycle greenhouse gas emissions of goods and services. British Standard, Department for Environment, Food and Rural Affairs, Carbon Trust. 2008. PAS 2050:2080. British Standard Institute, London, UK.

Canadian Dairy Information Centre. 2011a. Dairy Facts and Figures. The farm: Types of dairy barn. Accessed Feb. 20, 2012. http://www.infolait.gc.ca/index_e.php?s1=dff-fcil\&s2=farmferme\&page = barn

Canadian Dairy Information Centre. 2011b. Statistics of the Canadian Dairy Industry - Complete publication. Accessed Sep. 20, 2011. http://www.dairyinfo.gc.ca/pdf/publication_2011edition.pdf.

Capper, J. L., R. A. Cady, and D. E. Bauman. 2009. The environmental impact of dairy production: 1944 compared with 2007. J. Anim. Sci. 87:2160-2167.

Casey, J. W., and N. M. Holden. 2005. Analysis of greenhouse gas emissions from the average Irish milk production system. Agric. Syst. 86:97-114.

Cederberg, C., and M. Stadig. 2003. System expansion and allocation in life cycle assessment of milk and beef production. Int. J. Life Cycle Assess. 8:350-356.

CRAAQ (Centre de référence en agriculture et agroalimentaire du Québec). 2010. Référence économiques. Foin AGDEX 120/854, Maïs-fourrager AGDEX 111/821a, Maïs-grain AGDEX 111/821b, Soya AGDEX 141/821. CRAAQ, Québec, Canada.

Dalgaard, R., J. Schmidt, N. Halberg, P. Christensen, M. Thrane, and W. A. Pengue. 2008. LCA of soybean meal. Int. J. Life Cycle Assess. 13:240-254.

Environment Canada. 2010. National inventory report 19902008: Greenhouse gas sources and sinks in Canada. Accessed Apr. 6, 2011. http://www.ec.gc.ca/Publications/default. asp?lang $=$ En\&xml $=492 \mathrm{D} 914 \mathrm{C}-2 \mathrm{EAB}-47 \mathrm{AB}-\mathrm{A} 045-\mathrm{C} 62 \mathrm{~B} 2 \mathrm{C}-$ DACC29.

FAO (Food and Agriculture Organization of the United Nations). 2008. OECD-FAO Agricultural Outlook 2008-2017. FAO, Rome, Italy.

Flysjö, A., C. Cederberg, M. Henriksson, and S. Ledgard. 2011a. How does co-product handling affect the carbon footprint of milk? A case study of milk production in New Zealand and Canada. Int. J. Life Cycle Assess. 16:420-430.

Flysjö, A., M. Henriksson, C. Cederberg, S. Ledgard, and J.-E. Englund. 2011b. The impact of various parameters on the carbon footprint of milk production in New Zealand and Sweden. Agric. Syst. 104:459-469.

Gerber, P., T. Vellinga, C. Opio, B. Henderson, and H. Steinfeld. 2010. Greenhouse gas emissions from the dairy sector: A life cycle assessment. Food and Agriculture Organization of the United Nations (FAO), Animal Production and Health Division, Rome, Italy. 
Grainger, C., and K. A. Beauchemin. 2011. Can enteric methane emissions from ruminants be lowered without lowering their production? Anim. Feed Sci. Technol. 166-167:308-320.

IDF (International Dairy Federation). 2010. A common carbon footprint approach for dairy - The IDF guide to standard lifecycle assessment methodology for the dairy sector. In Bulletin of the IDF No. $445 / 2010$.

IPCC (Intergovernmental Panel on Climate Change). 2006. 2006 IPCC Guidelines for National Greenhouse Gas Inventories. H. S. Eggleston, L. Buendia, K. Miwa, T. Ngara, and K. Tanabe, ed. Prepared by the National Greenhouse Gas Inventories Programme. IGES, Japan. Accessed Jan. 15, 2011. http://www.ipcc-nggip.iges. or.jp/public/2006gl/index.htm.

IPCC (Intergovernmental Panel on Climate Change). 2007. Changes in atmospheric constituents and in radiative forcing. Chapter 2 in Climate Change 2007: The Physical Science Basis. Contribution of Working Group I to the Fourth Assessment Report of the Intergovernmental Panel on Climate Change. S. Solomon, D. Qin, M. Manning, Z. Chen, M. Marquis, K. B. Averyt, M. Tignor, and H. L. Miller, ed. Cambridge University Press, Cambridge, UK, and New York, NY.

ISO (International Organization for Standardization). 2006. Environmental Management, Life Cycle Assessment, Principles and Framework, Standard 14044. ISO, Geneva, Switzerland.

Johnson, K. A., and D. E. Johnson. 1995. Methane emissions from cattle. J. Anim. Sci. 73:2483-2492.

Kristensen, T., L. Mogensen, M. Trydeman Knudsen, and J. E. Hermansen. 2011. Effect of production system and farming strategy on greenhouse gas emissions from commercial dairy farms in a life cycle approach. Livest. Sci. 140:136-148.

Little, S., J. Linderman, K. Maclean, and H. Janzen. 2008. Holos-A tool to estimate and reduce greenhouse gases from farms. Methodology and algorithms for versions 1.1.x. Agriculture and Agri-Food Canada, Cat. No. A52-136/2008E-PDF.

Marshall, I. B., P. H. Schut, and M. Ballard. 1999. A national ecological framework for Canada: Attribute data. Environmental Quality Branch, Ecosystems Science Directorate, Environment Canada and Research Branch, Agriculture and Agri-Food Canada, Ottawa/Hull, Canada. Accessed Jan. 20, 2011. http://sis.agr.gc.ca/ cansis/nsdb/ecostrat/1999report/intro.html.

Moss, A. R., J.-P. Jouany, and J. Newbold. 2000. Methane production by ruminants: Its contribution to global warming. Ann. Zootech. 49:231-253.

Nagy, C. N. 2000. Energy and greenhouse gas emissions coefficients for inputs used in agriculture. Report to the Prairie Adaptation Research Collaborative. Centre for Studies in Agriculture, Law and the Environment, Saskatoon, SK, Canada.
NRC. 2001. Nutrient Requirement of Dairy Cattle. 7th rev. ed. Natl. Acad. Sci., Washington, DC.

O'Mara, F. P. 2011. The significance of livestock as a contributor to global greenhouse emissions today and in the near future. Anim. Feed Sci. Technol. 166-168:7-15.

Phetteplace, H. W., D. E. Johnson, and A. F. Seidl. 2001. Greenhouse gas emissions from simulated beef and dairy livestock systems in the United States. Nutr. Cycl. Agroecosyst. 60:99-102.

Rochette, P., D. E. Worth, R. L. Lemke, B. G. McConkey, D. J. Pennock, C. Wagner-Riddle, and R. L. Desjardins. 2008. Estimation of $\mathrm{N}_{2} \mathrm{O}$ emissions from agricultural soils in Canada. I. Development of a country-specific methodology. Can. J. Soil Sci. 88:641-654.

Rotz, C. A., F. Montes, and D. S. Chianese. 2010. The carbon footprint of dairy production systems through partial life cycle assessment. J. Dairy Sci. 93:1266-1282.

Schmidt, J. H. 2007. Life cycle assessment of rapeseed oil and palm oil. Part 3: Life cycle inventory of rapeseed oil and palm oil. PhD Thesis. Aalborg Univ., Aalborg, Denmark.

Sutton, J. D., and S. V. Morant. 1989. A review of the potential of nutrition to modify milk fat and protein. Livest. Prod. Sci. $23: 219-237$.

Thomassen, M., R. Dalgaard, R. Heijungs, and I. de Boer. 2008. Attributional and consequential LCA of milk production. Int. J. Life Cycle Assess. 13:339-349.

USDA. 2010. Dairy 2007, Heifer Calf Health and Management on US Dairy Operations. \# 550.0110. United States Department of Agriculture:Animal and Plant Health Inspection Service:Veterinary Services (USDA:APHIS:VS), Centers for Epidemiology and Animal Health (CEAH), Fort Collins, CO.

USDA. 2011. National nutrient database for standard reference. United States Department of Agriculture. Accessed Mar. 23, 2011. http://www.nal.usda.gov/fnic/foodcomp/search/.

Valacta Inc. 2009. L'évolution de la production laitière québécoise. In Le producteur de lait québécois. Valacta Inc., Sainte-Anne-deBellevue, QC, Canada.

Valacta Inc. 2010. Total performance index (Quebec). Accessed Dec. 16, 2010. http://www.agr.gc.ca/redmeat-vianderouge/pri_eng. htm\#cattle.

Vergé, X. P. C., J. A. Dyer, R. L. Desjardins, and D. Worth. 2007. Greenhouse gas emissions from the Canadian dairy industry in 2001. Agric. Syst. 94:683-693.

Weidema, B., H. Wenzel, C. Petersen, and K. Hansen. 2004. The product, functional unit and reference flows in LCA. Environmental News No. 70. Danish Environmental Protection Agency, Copenhagen, Denmark. 